\title{
EFFECTS OF AGE AND PARITY ON REPRODUCTION IN YOUNG FEMALE MICE
}

\author{
T. G. KENNEDY* AND J. P. KENNEDY \\ School of Wool and Pastoral Sciences, The University of New South Wales, \\ Kensington, N.S.W. 2033, Australia
}

(Received 7th January 1971, accepted 27th May 1971)

Summary. The effects of age and of parity on reproductive capacity were estimated by comparing old virgin with young virgin mice, and old parous with old virgin mice, respectively.

Increased age was associated with a greater body weight at 'joining', a smaller proportion of mice pregnant, a greater number of CL of pregnancy, a greater number of implantation sites at Day 5 or 6 of pregnancy, a greater number of viable fetuses at Day 18 of pregnancy, and a smaller proportion of CL represented as implantation sites at Day 5 or 6 of pregnancy.

Parity significantly increased body weight at 'joining' and the number of CL of pregnancy. The number of implantation sites at Day 5 or 6 of pregnancy and the number of viable fetuses at Day 18 of pregnancy were non-significantly greater for old parous than old virgin mice.

It was concluded from the relationships between body weight at 'joining' and the number of CL of pregnancy that the age and parity effects on the numbers of $\mathrm{CL}$, implantation sites and viable fetuses were due to differences between groups in body weight at mating.

\section{INTRODUCTION}

Murray (1934), Biggers, Finn \& McLaren (1962) and Rugh \& Wohlfromm (1967) have reported that litter size of mice showed an initial increase in the first two or three litters. Because of the correlation between parity and maternal age in these studies, it is not possible to attribute the changes in litter size to advancing maternal age, parity, or a combination of age and parity.

Some studies in the mouse have endeavoured to separate the effects of age and parity. Using relatively small groups of mice, Venge (1960) found a nonsignificant tendency for litter size to increase with increasing age of the mother. Nishimura \& Shikata (1960) investigated the reproductive capacity of virgin mice aged 10 to 12 months, multiparous mice of the same age, and virgin mice aged $1 \frac{1}{2}$ to 2 months. The average litter size at birth was smallest in elderly primipara whereas there was no significant difference in average litter size between elderly multipara and young primipara. Rugh \& Wohlfromm (1967)

* Present address: Department of Physiology, Health Sciences Centre, The University of Western Ontario, London, Ont., Canada. 
found that, when compared with virgin mice of the same age, multipara produced, on the average, larger litters.

Litter size is not a simple characteristic but is dependent on several components, including ovulation rate, the proportion of ova fertilized and prenatal mortality. This paper reports investigations aimed at explaining age and parity changes in the fertility of young mice in terms of ovulation rate and prenatal mortality.

\section{MATERIALS AND METHODS}

Experimental design

The study consisted of three experiments separated in time. In Exps 1 and 3, which were replicates, the numbers of CL of pregnancy and viable fetuses on Day 18 of pregnancy were compared in 14-week-old primiparous (OP), 14week-old nulliparous (OV) and 6-week-old nulliparous (YV) mice. In Exp. 2, the numbers of GL of pregnancy and implantation sites were compared in OP, $\mathrm{OV}$ and $\mathrm{YV}$ females. In these experimental designs, the parity effect was estimated by comparison between OP and OV groups, whereas the age effect was estimated by comparison between OV and YV groups.

The number of CL of pregnancy was used as an estimate of ovulation rate. The number of implantation sites was estimated from counts of the number of dye-reactive sites in the uterus following intravenous injection of Evan's Blue, as described by Psychoyos (1960). An estimate of litter size was obtained from counts of the number of normally developing fetuses (referred to as viable fetuses) found at autopsy on Day 18 of pregnancy. The day on which a copulation plug was detected was called Day 1 of pregnancy.

\section{Animals and animal management}

The mice, which were of the Sydney White strain, were kept in a room maintained on a constant light/dark regimen of $12 \mathrm{hr} / 12 \mathrm{hr}$. During the first two experiments, temperature was maintained within the range $21 \pm 2^{\circ} \mathrm{C}$ and humidity was not controlled. During the third experiment, temperature was maintained within the range $21 \pm 1^{\circ} \mathrm{C}$ and humidity between 50 and $60 \%$. Unrestricted access was allowed to water and a commercial pelleted mouse food.

Within each experiment, the OP and OV mice had all been born on the same day and were exactly 14 weeks old at the start of the experiments. The $\mathrm{OP}$ females had produced and reared one litter following mating at 6 weeks of age. The OV mice were litter mates of OP females. At 6 weeks of age, the two groups were formed by stratified random allocation based on body weight and parentage. While the OP group went through their first pregnancy and lactation, the OV females were kept at two per cage until they were 14 weeks old. The XV mice were exactly 6 weeks old at the start of the experiments.

Males which had previously sired a litter were placed with the females for 10 days in cages which contained two females, each of which belonged to a different group. Females were checked each morning for the presence of copulation plugs. Except for the exclusion of brother-sister, father-daughter 
and son-mother matings, males were assigned to ('joined' with) females at random.

In Exps 1 and 3, mice were killed by cervical dislocation on Day 18 of pregnancy and the numbers of CL and viable fetuses were counted on each side of the reproductive tract. In Exp. 2, females were killed between 09.30 and 12.30 hours on Day 5 of pregnancy, $15 \mathrm{~min}$ after an intravenous injection of $0.2 \mathrm{ml}$ of a $0.5 \%$ solution of Evan's Blue in normal saline. The numbers of CL and dye sites on each side of the reproductive tract were recorded. The small numbers of animals in which injection of the dye failed were killed on Day 6 of pregnancy and the number of implantation swellings as well as the number of GL was recorded.

\section{Statistical analysis}

Tests for the effects of age and parity on proportions were made on arcsin transformed percentages. Because the standard deviations were proportional to the means, body weights were transformed to logarithms. Experimental results were analysed by analysis of variance.

\section{RESULTS}

Effects of age and parity on body weight at 'joining' (Exps 1, 2 and 3)

The mean body weights of the OP, OV and YV females at the start of the experiments are given in Table 1.

TABLE 1

EFFECTS OF AGE AND PARITY ON THE BODY WEIGHT OF YOUNG FEMALE MICE

\begin{tabular}{|c|c|c|c|c|c|c|}
\hline \multirow[b]{2}{*}{ Experiment } & \multicolumn{6}{|c|}{ Mean ( \pm S.E.) after logarithmic transformation of body weight $(g)$ (with antilog) } \\
\hline & $\begin{array}{c}\text { No. of } \\
\text { mice }\end{array}$ & $\begin{array}{c}\text { Old parous } \\
(14 \text { weeks old*) }\end{array}$ & $\begin{array}{c}\text { No. of } \\
\text { mice }\end{array}$ & $\begin{array}{c}\text { Old virgin } \\
(14 \text { weeks old })\end{array}$ & $\begin{array}{c}\text { No. of } \\
\text { mice }\end{array}$ & $\begin{array}{l}\text { Young virgin } \\
(6 \text { weeks old } *)\end{array}$ \\
\hline 1 & 43 & $\begin{array}{c}1 \cdot 517 \pm 0 \cdot 008 \\
(32 \cdot 9)\end{array}$ & 48 & $\begin{array}{c}1.469 \pm 0.008 \\
(29.5)\end{array}$ & 54 & $\begin{array}{c}1 \cdot 336 \pm 0.006 \\
(21 \cdot 7)\end{array}$ \\
\hline 2 & 60 & $\begin{array}{c}1 \cdot 499 \pm 0 \cdot 005 \\
(31 \cdot 6)\end{array}$ & 60 & $\begin{array}{c}1.460 \pm 0.007 \\
(28 \cdot 8)\end{array}$ & 60 & $\begin{array}{c}1.351 \pm 0.005 \\
(22 \cdot 5)\end{array}$ \\
\hline 3 & 68 & $\begin{array}{c}1.526 \pm 0.005 \\
(33.6)\end{array}$ & 69 & $\begin{array}{c}1.508 \pm 0 \cdot 006 \\
(32 \cdot 2)\end{array}$ & 70 & $\begin{array}{c}1 \cdot 346 \pm 0 \cdot 005 \\
(22 \cdot 2)\end{array}$ \\
\hline
\end{tabular}

* Age at start of 'joining'.

Analysis of variance revealed significant age $x$ experiments and parity $\times$ experiments interactions. Mean body weights were significantly higher in OP than in OV females $(P<0.001)$ and in OV than in YV females $(P<0.001)$, but the presence of significant interactions limits the validity of these comparisons.

Effects of age and parity on the proportion of mice pregnant at Day 18 (Exps 1 and 3)

The proportions of mice which were pregnant on Day 18 in Exps 1 and 3 respectively were: 
OP mice: $33 / 43(76 \cdot 7 \%), 58 / 68(85 \cdot 3 \%)$

OV mice: $39 / 48(81.3 \%), 62 / 69(89.9 \%)$

YV mice: $52 / 54(96.3 \%), 70 / 70(100 \cdot 0 \%)$

Significantly $(P<0.05)$ more YV than OV females were pregnant at Day 18, but the differences between OP and OV mice were not significant.

Effects of age, parity and body weight on the number of corpora lutea (Exps 1, 2 and 3) The mean numbers of CL on both ovaries of OP, OV and YV mice in Exps 1,2 and 3 are given in Table 2.

\section{TABLE 2}

EFFEGTS OF AGE AND PARITY ON THE NUMBERS OF GORPORA LUTEA ON BOTH OVARIES OF OLD PAROUS, OLD VIRGIN AND YOUNG VIRGIN MIGE

\begin{tabular}{|c|c|c|c|c|c|c|}
\hline \multirow[b]{2}{*}{ Experiment } & \multicolumn{6}{|c|}{ Mean $( \pm S . E$.$) number of corpora lutea on both ovaries$} \\
\hline & $\begin{array}{l}\text { No. of } \\
\text { mice }\end{array}$ & $\begin{array}{c}\text { Old parous } \\
(14 \text { weeks old })\end{array}$ & $\begin{array}{l}\text { No. of } \\
\text { mice }\end{array}$ & $\begin{array}{c}\text { Old virgin } \\
(14 \text { weeks old })^{*}\end{array}$ & $\begin{array}{c}\text { No. of } \\
\text { mice }\end{array}$ & $\begin{array}{l}\text { Young virgin } \\
(6 \text { weeks old*) }\end{array}$ \\
\hline $\begin{array}{l}1 \\
2 \\
3\end{array}$ & $\begin{array}{l}33 \\
57 \\
58\end{array}$ & $\begin{array}{l}12.15 \pm 0.38 \\
13.05 \pm 0.23 \\
13.93 \pm 0.22\end{array}$ & $\begin{array}{l}39 \\
49 \\
62\end{array}$ & $\begin{array}{l}11 \cdot 38 \pm 0.41 \\
12.45 \pm 0.25 \\
13 \cdot 19 \pm 0.24\end{array}$ & $\begin{array}{l}52 \\
59 \\
70\end{array}$ & $\begin{array}{l}10.54 \pm 0.26 \\
10.91 \pm 0.19 \\
10.94 \pm 0.23\end{array}$ \\
\hline
\end{tabular}

* Age at start of 'joining'.

A significant age $\times$ experiments interaction was revealed by analysis of variance. Mean CL counts were greater in OP than in OV mice as shown by the significant $(P<0.01)$ parity effect, and were greater in OV than in YV females as shown by the significant $(P<0.001)$ age effect.

Regressions of CL counts on transformed body weight were not significantly different within groups between experiments, so the data were pooled within groups. For OP mice, the regression was described by:

$$
\mathrm{Y}=15 \cdot 735 \pm 3 \cdot 250 \mathrm{X}-10 \cdot 623
$$

where $=$ number of $\mathrm{CL}$

and $\mathrm{X}=$ logarithmic transformed body weight.

For OV and YV mice, the corresponding regressions were described by:

$$
\mathrm{Y}=13 \cdot 281 \pm 3 \cdot 090 \mathrm{X}-7 \cdot 204
$$

and

respectively.

$$
\mathrm{Y}=15 \cdot 452 \pm 3 \cdot 064 \mathrm{X}-9 \cdot 973
$$

The coefficients of all regressions were highly significantly $(P<0.001)$ different from zero. There were no significant differences between regressions due to age or parity. The pooled regressions of CL count on transformed body weight was described by:

$$
\mathrm{Y}=13 \cdot 820 \pm 0 \cdot 947 \mathrm{X}-7 \cdot 832
$$

Following adjustment by covariance analysis (Snedecor, 1956) for differences in body weight at 'joining', the mean number of CL did not differ significantly between groups. The adjusted means are presented in Table 3. 
TABLE 3

EFFEGTS OF AGE AND PARITY ON THE MEAN GORPORA LUTEA COUNTS OF OLD PAROUS, OLD VIRGIN AND YOUNG VIRGIN MICE FOLLOWING ADJUSTMENT OF COUNTS FOR DIFFERENCES IN BODY WEIGHT AT THE START OF EXPERIMENTS

\begin{tabular}{l|c}
\hline Group & Adjusted mean CL count \\
\hline Old parous (14 weeks old*) & $12 \cdot 18$ \\
Old virgin (14 weeks old*) & 11.90 \\
Young virgin (6 weeks old*) & $12 \cdot 13$ \\
\hline
\end{tabular}

* Age at start of 'joining'.

Effects of age and parity on the number of implantation sites at Day 5 or 6 of pregnancy (Exp. 2)

Intravenous injection of Evan's Blue was successful in 54/57, 45/49 and 56/59 of OP, OV and YV females, respectively. Mean numbers of implantation sites are presented in Table 4 . There were significantly more $(P<0.05)$ implantation

TABLE 4

EFFECTS OF AGE AND PARITY ON THE MEAN NUMBER OF IMPLANTATION SITES AT DAY 5 OR 6 OF PREGNANCY IN OLD PAROUS, OLD VIRGIN AND YOUNG VIRGIN MIGE (EXPERIMENT 2)

\begin{tabular}{l|c|c}
\hline \multicolumn{1}{c|}{ Group } & $\begin{array}{c}\text { No. of } \\
\text { mice }\end{array}$ & $\begin{array}{c}\text { Mean }( \pm \text { S.E. }) \text { number of } \\
\text { implantation sites }\end{array}$ \\
\hline Old parous (14 weeks old*) & 57 & $11 \cdot 98 \pm 0 \cdot 31$ \\
Old virgin (14 weeks old*) & 49 & $11 \cdot 31 \pm 0.32$ \\
Young virgin (6 weeks old*) & 59 & $10 \cdot 29 \pm 0.27$ \\
\hline
\end{tabular}

* Age at start of 'joining'.

sites on OV than YV females but, although OP females had more implantation sites than OV females, the difference was not significant.

The proportions of $\mathrm{cL}$ represented as implantation sites were 683/744 $(91.8 \%)$ for OP mice, $554 / 610(90.8 \%)$ for OV mice and $607 / 644(94.3 \%)$ for YV mice. Age, but not parity, was a significant $(P<0.05)$ effect on these proportions.

Effects of age and parity on the number of viable fetuses at Day 18 of pregnancy (Exps 1 and 3)

The mean number of viable fetuses are presented in Table 5.

In an analysis of variance of the data, the only significant $(P<0.01)$ effect was age, which was expressed by a greater number of fetuses in OV than YV females.

The proportions of cL represented as viable fetuses at Day 18 of pregnancy in Exps 1 and 3, respectively, were: 


$$
\begin{aligned}
& \text { OP mice: } 290 / 401(72.3 \%), 592 / 808(73.3 \%) \\
& \text { OV mice: } 319 / 444(71.9 \%), 623 / 818(76.2 \%) \\
& \text { YV mice: } 401 / 548(73.2 \%), 577 / 766(75.3 \%)
\end{aligned}
$$

Age and parity were not significant effects on these proportions.

TABLE 5

\begin{tabular}{|c|c|c|c|c|c|c|}
\hline \multirow[b]{2}{*}{ Experiment } & \multicolumn{6}{|c|}{ Mean ( \pm S.E.) number of viable fetuses at Day 18 of pregnancy } \\
\hline & $\begin{array}{l}\text { No. of } \\
\text { mice }\end{array}$ & $\begin{array}{c}\text { Old parous } \\
(14 \text { weeks old })^{2}\end{array}$ & $\begin{array}{l}\text { No. of } \\
\text { mice }\end{array}$ & $\left.\begin{array}{c}\text { Old virgin } \\
(14 \text { weeks old }\end{array}\right)$ & $\begin{array}{l}\text { No. of } \\
\text { mice }\end{array}$ & $\begin{array}{c}\text { Young virgin } \\
(6 \text { weeks old })\end{array}$ \\
\hline $\begin{array}{l}1 \\
3\end{array}$ & $\begin{array}{l}33 \\
57\end{array}$ & $\begin{array}{r}8 \cdot 79 \pm 0 \cdot 50 \\
10 \cdot 39 \pm 0.49\end{array}$ & $\begin{array}{l}39 \\
62\end{array}$ & $\begin{array}{r}8 \cdot 18 \pm 0.48 \\
10.05 \pm 0.40\end{array}$ & $\begin{array}{l}52 \\
70\end{array}$ & $\begin{array}{l}7 \cdot 71 \pm 0.41 \\
8 \cdot 24 \pm 0.36\end{array}$ \\
\hline
\end{tabular}

EFFECTS OF AGE AND PARITY ON THE NUMBERS OF VIABLE FETUSES AT DAX 18 OF PREGNANCY IN OLD PAROUS, OLD VIRGIN AND YOUNG VIRGIN MIGE

* Age at start of 'joining'.

\section{DISCUSSION}

Biggers et al. (1962) have shown that the relation of litter size to litter order in the mouse is a pattern in which there is an initial rise in litter size, and have attempted to distinguish between the effects of age and parity on various components of reproduction. The results reported here show that nulliparous female mice of differing ages at first mating (14 weeks versus 6 weeks) also differed in average litter size on Day 18 of their first pregnancy and in the proportion pregnant. Litter size was greater in the older mice but more of the young mice were pregnant. These differences, which have been regarded as age effects, can be explained by the observations of higher ovulation rate (measured by counts of CL) and greater number of implantation sites in the older mice. It was also apparent that fertilization failure and/or early embryonic mortality was lower in younger mice where a greater proportion of GL were represented as implantation sites at Days 5 to 6 of pregnancy. However, embryonic loss as measured by the proportion of CL represented by viable embryos at Day 18, did not differ between young and older mice during the whole of pregnancy.

Comparison between mice of the same age (14 weeks at mating), but differing in being either primiparous or nulliparous, revealed that there were not any significant differences in average litter size or proportions of mice pregnant but that there was a significantly higher ovulation rate in primipara compared with nullipara. These differences have been regarded as parity effects.

Our finding of greater ovulation rate in older mice contrasts with the report of MacDowell, Allen \& MacDowell (1929) who found that, as age increased, the average number of $\mathrm{CL}$ within the same parity group remained practically constant. Nishimura \& Shikata (1960) were also unable to detect an age effect when they compared CL counts in virgin mice aged 10 to 12 months and $1 \frac{1}{2}$ to 2 months. Our finding of a parity effect on ovulation rate, however, agrees with the results of these two groups of workers.

The greater preimplantation loss of ova and embryos in older nullipara may 
be related to the higher ovulation rate in the older mice as Bowman \& Roberts (1958) and Harper (1964) have reported that the proportion of ova lost before implantation is positively associated with ovulation rate. However, ovulation rate was also greater in primipara than in nullipara of the same age yet there was not a significant parity effect on the proportion of CL represented by implantation sites. The explanation of these divergent results may be that the age effect on ovulation rate was relatively greater than the parity effect. Since age was not a significant effect on the proportion of CL represented by viable fetuses and in view of the greater preimplantation loss in older mice, it must be assumed that young nullipara lose more embryos during and/or after implantation than do older nullipara.

In all groups of mice, there was a highly significant positive relationship between body weight, after logarithmic transformation, and CL count. The regression of cL count on untransformed body weight, although significant, did not fit the data as well. MacDowell et al. (1929) reported that there was a non-linear relationship between body weight and cL count in mice. In their data, the relationship did not hold above body weights of $24 \mathrm{~g}$.

As our data indicate that age and parity effects on litter size are related to variation in ovulation rate, it follows that the principal source of age and parity effects is the difference between groups in body weight at mating. The mechanisms by which body weight affects ovulation rate are unknown but they appear to be independent of body composition as the regression of CL count on body weight did not differ between age and parity groups. Body composition of mice in the various groups probably differed for the young nulliparous females were still growing rapidly and so probably contained less fat than older mice.

The lower pregnancy rate in the older mice is surprising as in some colonies of Sydney White mice, the females are not mated until they are about 12 weeks of age (Bindon \& Lamond, 1966). The cause of the decline in fertility in older mice is not known but it appears to be due to failure to mate as we found that copulation plugs were detected in significantly fewer older mice in all experiments.

\section{ACKNOWLEDGMENTS}

This study was carried out while T.G.K. was the recipient of an Australian Wool Board Post-Graduate Scholarship.

\section{REFERENGES}

Biggers, J. D., Finn, G. A. \& McLaren, A. (1962) Long-term reproductive performance of female mice. II. Variation of litter size with parity. F. Reprod. Fert. 3, 313.

Bindon, B. M. \& LAmond, D. R. (1966) Description of a mouse colony used for research in reproductive physiology. F. Inst. Anim. Techns, 17, 6.

Bowman, J. C. \& Roberts, R. C. (1958) Embryonic mortality in relation to ovulation rate in the house mouse. F. exp. Biol. 35, 138.

HARPER, M. J. K. (1964) Observations on amount and distribution of prenatal mortality in a strain of albino rats. 7. Reprod. Fert. 7, 185.

MacDowell, E. G., Allen, E. \& MacDowelt, C. G. (1929) The relation of parity, age, and body weight to the number of corpora lutea in mice. Anat. Rec. 41, 267. 
Murray, W. S. (1934) The breeding behaviour of the dilute brown stock of mice (Little dba). Am. $\mathcal{F}$. Cancer, 20, 573.

NrshmuRA, H. \& Shikata, A. (1960) High embryonic mortality of the mouse fetuses from the elderly primigravid mothers. Okijimas Folia anat. jap. 36, 151.

Psycнoyos, A. (1960) La réaction déciduale est précédée de modifications précoces de la perméabilité capillaire de l'utérus. C.r. Séanc. Soc. Biol. 154, 1384.

Rugh, R. \& WoHLFROMm, M. (1967) The reproductive performance of the laboratory mouse: maternal age, litter size and sex ratios. Proc. Soc. exp. Biol. Med. 126, 685.

Snedecor, G. W. (1956) Statistical methods, 5th edn. State College Press, Iowa.

Venge, O. (1960) Age at first mating and reproduction in mice. K. LantbrHögsk. Annir, 26, 251. 